\title{
Mature plant and tissue resistance in the groundnut-peanut bud necrosis virus system
}

\author{
A.A.M. Buiel ${ }^{1,2} \&$ J.E. Parlevliet ${ }^{2}$ \\ ${ }^{1}$ Crop Protection Division, International Crops Research Institute for the Semi-Arid Tropics (ICRISAT) Asia \\ Center, Patancheru 502 324, Andhra Pradesh, India; ${ }^{2}$ Department of Plant Breeding; Wageningen Agricultural \\ University, P.O. Box 386,6700 AJ Wageningen, The Netherlands
}

Received 18 September 1995; accepted 12 April 1996

Key words: Arachis hypogaea L., groundnut, incidence, incubation period, mature plant resistance, peanut bud necrosis virus, tomato spotted wilt virus

\section{Summary}

Leaves and plants of different ages of a susceptible and two resistant groundnut genotypes were mechanically inoculated with peanut bud necrosis virus, and the percentage of plants with systemic symptoms (incidence) and the incubation period were determined. The incidence decreased sharply in all three genotypes with the age of the inoculated leaves and plants. The incubation period increased with the age of leaves and plants. Apparently, only young tissue of young plants is susceptible, while mature tissue and plants are highly resistant. This mature tissue and plant resistance occurs irrespective of the susceptibility level of the genotype to peanut bud necrosis virus, however, it develops earlier in the resistant than in the susceptible genotypes.

Abbreviations: $\mathrm{IP}_{50}$ - incubation period; PBNV - peanut bud necrosis virus; TSWV - tomato spotted wilt virus

\section{Introduction}

Peanut bud necrosis virus (PBNV) causes a serious disease in groundnut (Arachis hypogaea L.) in Asia. The virus is presumably a distinct member in the genus Tospovirus of the Bunyaviridae (Reddy et al., 1992). Plants infected with PBNV have a strongly reduced yield, or do not yield at all. Natural infection can be very high, e.g. in India an average of $46 \%$ in seven environments was reported in TMV 2, the predominantly grown groundnut cultivar (Buiel \& Parlevliet, 1995). Resistance is therefore extremely important to reduce yield losses caused by PBNV.

Complete resistance (immunity) has not been found in the cultivated groundnut (Reddy et al., 1991). However, resistance of a quantitative nature is present in groundnut and is expressed as a reduced percentage of systemically infected plants.. This quantitative resistance is characterized by a wide variation (Buiel et al., 1995), and occurs both when naturally infected by thrips in the field, and when mechanically inoculated.
In addition to complete resistance and quantitative resistance, a third type described as mature plant resistance has been reported from many other hostpathogen systems, such as bean-tobacco mosaic virus (Schein, 1965), Nicotiana glutinosa-lettuce necrotic yellows virus (Crowley, 1967), potato-potato virus X (Venekamp \& Beemster, 1980; Wislocka, 1984), potato-potato virus $\mathrm{Y}^{0}$ (Sigvald, 1985), potato-potato leaf roll virus and potato-potato virus $Y$ (Beemster, 1987), barley-barley leaf rust (Smit \& Parlevliet, 1990 ), potato-potato virus $Y^{0}$ and potato-potato virus $\mathrm{Y}^{N}$ (Gibson, 1991), and rice-rice blast (Roumen, 1992; Roumen et al., 1992). Mature plant resistance is generally genotype independent, i.e. it occurs in all genotypes, even in the most susceptible ones (Smit \& Parlevliet, 1990). It has not been described for groundnutPBNV.

Bald (1937) studied inter alia the mature plant resistance of tomato to tomato spotted wilt virus (TSWV, the type member of the genus Tospovirus) in Australia. He observed a delay in the incubation period 
in mature plants compared to young plants. No further studies on mature plant resistance in the tomato-TSWV system were reported after Bald's publication, nor on any other host-Tospovirus system. Yet on groundnut, Savary (1987) described an effect of plant development and leaf age on the resistance to rust (Puccinia arachidis).

In this study, the occurrence of mature plant resistance in the groundnut-PBNV system was investigated. Three groundnut genotypes and one PBNV isolate were used to determine the effect of leaf and plant age on the percentage of plants with systemic symptoms (incidence) and the incubation period.

\section{Materials and methods}

\section{Mechanical inoculation}

The PBNV isolate used was originally collected at ICRISAT, Asia Center, India. The virus was not more than six times mechanically transmitted to plants of the susceptible genotype TMY 2, to minimize the risk of generating defective interfering RNA mutants, as was shown to occur in TSWV (Resende et al., 1991). Inoculum was prepared by grinding systemically infected leaves of TMV 2 plants with clear chlorotic ring spots in $0.05 \mathrm{M}$ phosphate buffer, $\mathrm{pH} 7.0$ containing 0.01 $\mathrm{M} \mathrm{Na}_{2} \mathrm{SO}_{3}(1: 10, \mathrm{w} / \mathrm{v})$. This extract was kept chilled during the inoculation of the test plants: The plants were grown in a greenhouse with minimum/maximum temperatures of $15-20^{\circ} \mathrm{C} / 25-35^{\circ} \mathrm{C}$.

The incidence of systemically infected plants was recorded daily. The incubation period $\left(\mathrm{IP}_{50}\right)$ was determined as the interval between inoculation and the appearance of the first systemic symptoms on $50 \%$ of the ultimately infected plants. In the absence of any systemically infected plants, it was assumed that the $\mathrm{IP}_{50}$ was at least longer than the last observation date $(x)$. Here, $x+1$ was used in the computations.

\section{Leaf age}

The effect of leaf age was tested on three groundnut genotypes, JL 24 (susceptible), ICGV 86031 (resis$\operatorname{tant}$ ), and ICGV 86388 (resistant). To inoculate leaves of different ages at the same time, pre-germinated seeds were sown in $15 \mathrm{~cm}$ diameter pots at two-day intervals. The third leaf (numbered in order of appearance) of each plant was inoculated on 10,12 , and 14 days after sowing. The third leaves were unfolded (leaf age 1), expanded (leaf age 2), and expanded and matured (leaf age 3).

The experiments were repeated three times (senes 1 to 3) and consisted of two or three replicates. Each treatment comprised five pots with five plants each. Plants were removed before inoculation when the third leaf did not develop uniformly with the others within the same treatment. The three series were mechanically sap-inoculated on 9 January 1991, 5 August 1994, and 4 October 1994.

\section{Plant age}

To test the effect of plant age, leaves at different positions, but with identical age were inoculated. Pregerminated seeds of JL 24, ICGV 86031, and ICGV 86388 were sown in $15 \mathrm{~cm}$ diameter pots at regular intervals to inoculate leaves at different positions at the same time. Leaves were numbered in order of their appearance: the first two quadrifoliate leaves, leaf 1 and 2 appear simultaneously (2-leaf stage), followed by leaf 3, (3-leaf stage), leaf 4 (4-leaf stage) etc. From plants in the 2- to 5-leaf stage, one unfolded quadrifoliate leaf was inoculated per plant.

Three tests (series 4 to 6 ) were performed, each comprising three or four replicates. Every treatment comprised five pots with five plants each. Plants were removed before inoculation when the newly formed leaf layer was still folded or already expanded. Mechanical sap- inoculation of these three series was performed on 12 March 1991, 24 February 1993, and 10 January 1995.

\section{Results}

\section{Incidence in relation to leaf age}

The percentage of systemically infected plants (incidence) was monitored up to 23 days after inoculation (DAI) for series 1,21 DAI for series 2, and 20 DAI for series 3 . The average incidence of infected plants of JL 24 for leaf age 1 (unfolded) was $100.0 \%$ in series 1 , $91.4 \%$ in series 2 , and $98.0 \%$ in series 3 .

The genotype and treatment means of the incidence and the standard deviation of the means over series 1 to 3 were calculated, and shown in Table 1 . In all three genotypes a strong and significant reduction in the incidence of infected plants was observed when the leaf age was increased. In JL 24 the incidence reduced from $96 \%$ for leaf age 1 (unfolded) to $67 \%$ for leaf 
Table 1. Mean incidence (\%), standard deviation of the mean, and overall mean after inoculation of the third leaf at different leaf ages, of three groundnut genotypes

\begin{tabular}{llrrrr}
\hline Leaf age & \multicolumn{4}{c}{ Genotype } & \multirow{2}{*}{$\begin{array}{c}\text { Overall } \\
\text { mean }\end{array}$} \\
\cline { 3 - 5 } & & \multicolumn{5}{c}{ JL 24 } & ICGV & ICGV & 86031 & 86388 & \\
\hline 1 (unfolded) & mean $^{1}$ & 96.0 & 67.3 & 52.4 & $71.9 \mathrm{a}^{3}$ \\
& s.d. $^{2}$ & 2.2 & 7.8 & 6.8 & \\
2 (expanded) & mean & 66.7 & 27.5 & 21.0 & $38.4 \mathrm{~b}$ \\
& s.d. & 10.0 & 10.6 & 6.3 & \\
3 (expanded) & mean & 11.9 & 9.1 & 5.2 & $8.7 \mathrm{c}$ \\
and matured) & s.d. & 3.1 & 3.9 & 3.4 & \\
\hline
\end{tabular}

1. Mean incidence (\%).

2. Standard deviation of the mean incidence.

3. Different characters indicate significant differences (Tukey, $P<0.001)$.

age 2 (expanded). A further raise in maturity to leaf age 3 (expanded and matured) reduced the incidence to $12 \%$. The incidence of infected plants decreased in ICGV 86031 from 67\% (leaf age 1) to $27 \%$ (leaf age 2) and to $9 \%$ for leaf age 3 . Similarly, the values of ICGV 86388 reduced from $52 \%$ to $21 \%$ (leaf age 2 ) and to $5 \%$ (leaf age 3 ).

The greatest reduction in incidence for JL 24 (55\%) was found when plants with leaf age 2 and leaf age 3 were compared. On the other hand, the greatest reduction for the two resistant genotypes (36\% on average) was found when the leaf age increased from leaf age 1 to leaf age 2 , thus at an earlier stage than in JL 24 .

\section{Incidence in relation to plant age}

The incidence was monitored up to $20 \mathrm{DAI}$ for series 4, 16 DAI for series 5, and 10 DAI for series 6. JL 24, in the 3-leaf stage, had an average incidence of $86.9 \%$ in series $4,97.1 \%$ in series 5 , and $98.8 \%$ in series 6 .

The genotype and treatment means of the incidence, and the standard deviation of the means over series 4 to 6 were calculated, and presented in Table 2 . The incidence of infected plants in the three genotypes tested, decreased strongly and significantly with the plant age. In JL 24 the incidence of the 2-leaf stage (89\%) and the 3-leaf stage (94\%) did not differ significantly. Raising the plant age from the 3-leaf stage to the 4-leaf stage reduced the incidence to $71 \%$. Increasing the plant age to the 5-leaf stage dropped the incidence subsequently to $20 \%$ (Table 2). In the resistant genotypes, the incidence of infected plants of the 3-leaf stage was signifi-
Table 2. Mean incidence (\%), standard deviation of the mean, and overall mean after inoculation of the unfolded leaf from plants at different plant ages, of three groundnut genotypes

\begin{tabular}{|c|c|c|c|c|c|}
\hline \multirow[t]{2}{*}{ Plant age } & & \multicolumn{3}{|c|}{ Genotype } & \multirow{2}{*}{$\begin{array}{l}\text { Overall } \\
\text { mean }\end{array}$} \\
\hline & & JL 24 & ICGV & ICGV & \\
\hline \multirow[t]{2}{*}{ 2-leaf stage } & mean $^{l}$ & 89.0 & 57.1 & 46.9 & $64.3 \mathrm{a}^{3}$ \\
\hline & s.d. ${ }^{2}$ & 6.7 & 12.0 & 10.5 & \\
\hline \multirow[t]{2}{*}{ 3-leaf stage } & mean & 94.4 & 37.6 & 27.0 & $53.0 \mathrm{~b}$ \\
\hline & s.d. & 2.2 & 7.6 & 6.1 & \\
\hline \multirow[t]{2}{*}{ 4leaf stage } & mean & 71.2 & 4.9 & 4.5 & $26.9 c$ \\
\hline & s.d. & 7.5 & 1.8 & 1.7 & \\
\hline \multirow[t]{2}{*}{ 5-leaf stage } & mean & 20.0 & 3.3 & 12.0 & $11.8 \mathrm{c}$ \\
\hline & s.d. & 7.8 & 3.3 & 1.5 & \\
\hline
\end{tabular}

1. Mean incidence (\%).

2. Standard deviation of the mean incidence.

3. Different characters indicate significant differences (Tukey, $P<0.001)$.

cantly lower than the incidence of the 2-leaf stage. The values decreased further when plant age was increased to the 4- and 5-leaf stage.

The major reduction in incidence was observed between the 4- and 5-leaf stage in JL 24 (51\%), whereas for the resistant genotypes this was observed between the 3 - and 4-leaf stage ( $28 \%$ on average). The 3-leaf stage had a lower incidence than the 2-leaf stage in the resistant genotypes, but not in the susceptible genotype.

\section{Incubation period}

The incubation period $\left(\mathrm{IP}_{50}\right)$ clearly increased with leaf age (Table 3 ). The overall treatment means of $\mathrm{IP}_{50}$ increased with about 2.5 days between leaf age 1 (unfolded) and leaf age 2 (expanded). A further increase in $\mathrm{IP}_{50}$ of 4 days was observed when the leaf age was raised from leaf age 2 (expanded) to leaf age 3 (expanded and matured).

The $\mathrm{IP}_{50}$ also increased with plant age, except in young plants, i.e. younger than the 3-leaf stage (Table 4). The overall treatment means of $\mathrm{IP}_{50}$ were not significantly different between these plants. The $\mathrm{IP}_{50}$ raised with 3.5 days from plants in the 3 - leaf stage to the 4leaf stage. Increasing the plant age to the 5-leaf stage raised the $\mathrm{IP}_{50}$ with another 3.3 days.

The IP 50 found for the genotypes used here did not differ much. The $\mathrm{IP}_{50}$ was generally short in JL 24, and 
Table 3. Mean incubation period $\left(\mathrm{IP}_{50}\right)$, standard deviation of the mean, and overall mean after inoculation of the third leaf at different leaf ages, of three groundinut genotypes

\begin{tabular}{|c|c|c|c|c|c|}
\hline \multirow[t]{2}{*}{ Leaf age } & & \multicolumn{3}{|c|}{ Genotype } & \multirow{2}{*}{$\begin{array}{l}\text { Overall } \\
\text { mean }\end{array}$} \\
\hline & & JL 24 & ICGV & ICGV & \\
\hline \multirow[t]{2}{*}{1 (unfolded) } & mean' & $8.0^{\prime}$ & 9.0 & 9.4 & $8.8 \mathrm{a}^{3}$ \\
\hline & s.d. ${ }^{2}$ & 0.57 & .0 .65 & 0.96 & \\
\hline \multirow[t]{2}{*}{2 (expanded) } & mean & 9.6 & 12.5 & 12.0 & $11.4 \mathrm{~b}$ \\
\hline & s.d. & 0.48 & 1.71 & 1.64 & \\
\hline 3 (expanded & mean & 13.2 & 15.2 & 17.8 & $15.4 \mathrm{c}$ \\
\hline and matured) & s.d. & 2.87 & 3.12 & 3.47 & \\
\hline
\end{tabular}

1. Mean IP 50 (days).

2. Standard deviation of the mean $\mathrm{IP}_{50}$.

3. Different characters indicate significant differences (Tukey, $P<0.05)$.

longer in ICGV 86031 and ICGV 86388 (Tables 3 and 4).

\section{Discussion}

The occurrence of mature plant resistance in groundnut to PBNV is shown here. Both increased leaf and plant age reduced the incidence strongly and increased the incubation period. This effect (a decreased incidence and an increased incubation period) can be explained by a decreased rate of virus multiplication at the entry site, and/or a decreased rate of virus transport from the entry site to other plant parts. In another study we found that older, systemically infected tissue, diminished virus multiplication (data not shown).

The effect of mature leaves and mature plants on the incubation period of resistant genotypes is almost certainly underestimated. The incidence in resistant genotypes was low and therefore the assumption $\mathrm{IP}_{50}=\mathrm{x}+1$ was applied, while the actual incubation period could have been considerably higher.

It seems that only young tissue of young plants is susceptible. An increase in leaf or plant age of a few days induces a mature plant resistance resulting in a longer incubation period and fewer infected plants. This mature plant resistance occurs irrespective of the level of susceptibility of the groundnut genotype.

The observations on mature plant resistance of groundnut to PBNV ate in agreement with the results of Bald (1937) of TSWV on tomato, and with the results of Savary (1987) of rust on groundnut. Mature
Table 4. Mean incubation period ( $\mathrm{IP}_{50}$ ), standard deviation of the mean, and overall mean after inoculation of the unfolded leaf from plants at different plant ages, of three groundnut genotypes

\begin{tabular}{|c|c|c|c|c|c|}
\hline \multirow[t]{2}{*}{ Plant age } & & \multicolumn{3}{|c|}{ Genotype } & \multirow{2}{*}{$\begin{array}{l}\text { Overall } \\
\text { mean }\end{array}$} \\
\hline & & JL 24 & ICGV & ICGV & \\
\hline \multirow[t]{2}{*}{ 2-leaf stage } & mean $^{1}$ & 8.6 & 10.0 & 9.9 . & $9.5 \mathrm{a}^{3}$ \\
\hline & s.d. ${ }^{2}$ & 0.43 & 1.89 & 1.96 & \\
\hline \multirow[t]{2}{*}{ 3-leaf stage } & mean & 8.9 & 9.0 & 10.2 & $9.4 \mathrm{a}$ \\
\hline & s.d. & 0.39 & 0.56 & 0.44 & \\
\hline \multirow[t]{2}{*}{ 4-leaf stage } & mean & 10.3 & 14.1 & 14.2 & $12.9 \mathrm{~b}$ \\
\hline & s.d. & 0.47 & 1.27 & 1.47 & \\
\hline \multirow[t]{2}{*}{ 5-leaf stage } & mean & 14.3 & 19.7 & 14.7 & $16.2 \mathrm{c}$ \\
\hline & s.d. & 1.33 & 1.33 & 0.66 & \\
\hline
\end{tabular}

1. Mean $\mathrm{IP}_{50}$ (days).

2. Standard deviation of the mean $\mathrm{IP}_{50}$.

3. Different characters indicate significant differences (Tukey, $\mathrm{P}<0.01)$.

plant and tissue resistance in the groundnut - PBNV system is an effective and highly important feature in the epidemiology of PBNV. Under field conditions the groundnut crop is expected to become more resistant during the growing period as a result of mature plant resistance. Buiel \& Parlevliet (1995) showed that this effect did indeed occur in the field, in a study on six genotypes ranging from susceptible to resistant.

In this study it was shown that mature plant resistance occurred in susceptible as well as resistant genotypes. But, mature plant resistance developed earlier in resistant genotypes; and had a much larger effect on incidence than in the susceptible genotype. Furthermore, the $\mathrm{IP}_{50}$ was longer in the resistant genotypes than in the susceptible genotype and this directly and indirectly affects the development of the disease. Firstly, a longer $\mathrm{IP}_{50}$ directly slows down the rate of infection in a resistant crop. Secondly, it indirectly decreases the spread of the virus by thrips as fewer virus sources occur. The effect of mature plant resistance is altogether much larger in resistant genotypes, and the use of resistant genotypes can therefore be recommended to keep peanut bud necrosis disease at a low level.

\section{Acknowledgements}

This work was funded by the Directorate General for International Cooperation of the Ministry of Foreign Affairs, The Netherlands, and the work was carried out 
at ICRISAT, Asia Center, at the Virology Unit, Crop Protection Division. The authors are grateful to Drs D.V.R. Reddy and D. McDonald for extending their support, and to Dr D. Peters for critical reviews of the manuscript.

\section{References}

Bald, J.G., 1937. Investigations on spotted wilt of tomatoes. III Infection in field plots. Bull. Council Sci. Ind. Res. Australia Nr $106,32 \mathrm{pp}$.

Beemster, A.B.R., 1987. Virus translocation and mature plant resistance in potato plants. In: J.A. de Bokx \& J.P.H. van der Want (Eds). Viruses of potatoes and seed-potato production: pp. 116125. 2nd ed. Wageningen Pudoc.

Buiel, A.A.M. \& J.E. Parlevliet, 1995. Epidemiology of peanut bud necrosis disease in groundnut in India. In: A.A.M. Buiel, J.E. Parlevliet \& J.M. Lenné (Eds). Recent studies on peanut bud necrosis disease in India: Proceedings of a meeting, $20 \mathrm{March}$ 1995, ICRISAT Asia Center, India. pp. 41-46.

Buiel, A.A.M., S.L. Dwivedi, M.V.R. Prasad, A.B. Singh, P.S. Dharmaraj \& J.E. Parlevliet, 1995. Multi-environment testing for reduced incidence of peanut bud necrosis disease in India. In: A.A.M. Buiel, J.E. Parlevliet \& J.M. Lenné (Eds). Recent studies on peanut bud necrosis disease in India: Proceedings of a meeting, 20 March 1995, ICRISAT Asia Center, India. pp. 47-54.

Crowley, N.C., 1967. Factors affecting the local lesion response of Nicotiana glutinosa to lettuce necrotic yellows virus. Virology 31: 107-113.

Gibson, R.W., 1991. The development of mature plant resistance in four potato cultivars against aphid-inoculated potato virus $Y(O)$ and $Y(N)$. Potato Research 43: 205-210.
Reddy, D.V.R., J.A. Wightman, R.J. Beshear, B. Highland, M. Black, P. Sreenivasulu, S.L. Dwivedi, J.W. Demski, D. McDonald, Jr J.W. Smith \& D.H. Smith, 1991. Bud necrosis: a disease of groundnut caused by tomato spotted wilt virus. Information Bulletin no. 31. Patancheru A.P. 502 324, India: ICRISAT, 20 p.

Reddy, D.V.R., A.S. Ratna, M.R. Sudarshana, F. Poul \& I. Kiran Kumar, 1992. Serological relationships and purification of bud necrosis virus, a tospovirus occurring in peanut (Arachis hypogaea L.) in India. Annals of Applied Biology 120: 279-286.

Resende, R. de O., P. de Haan, A.C. de Avila, E.W. Kitajima, R. Kormelink, R. Goldbach \& D. Peters, 1991. Generation of envelope and defective interfering RNA mutants of tomato spotted wilt virus by mechanical passage. Journal of General Virology 72: 2375-2383.

Roumen, E.C., 1992. Effect of leaf age on components of partial resistance in rice to leaf blast. Euphytica 63: 271-279. Roumen, E.C., J.M. Bonman \& J.E. Parlevliet, 1992. Leaf age related partial resistance to Pyricularia oryzae in tropical lowland rice cultivars as measured by the number of sporulating lesions. Phytopathology 82: 1414-1417.

Savary, S., 1987. Decrease by plant development and leaf age of susceptibility of groundnut to rust (Puccinia arachidis) in a susceptible cultivar. Netherlands Joumal of Plant Pathology 93: 25-31.

Schein, R.D., 1965. Age-correlated changes in susceptibility of bean leaves to Uromyces phaseoli and tobacco mosaic virus. Phytopathology 55: 454-457.

Sigvald, R., 1985. Mature-plant resistance of potato plants against potato virus $Y^{0}$ (PVYO). Potato Research 28: 135-143. Smit, G. \& J.E. Parlevliet, 1990. Mature plant resistance of barley to barley leaf rust, another type of resistance. Euphytica 50: 159-162.

Venekamp, J.H. \& A.B.R. Beemster, 1980. Mature plant resistance of potato against some virus diseases. I Concurrence of development of mature plant resistance against potato virus $X$, and decrease of ribosome and RNA content. Netherlands Joumal of Plant Pathology 86:1-10.

Wislocka, M., 1984. Influence of weather factors on the increase of mature plant resistance to PVY. The Potato (1983-1984): 105116. 